\author{
Iwona Radziszewska
}

\title{
Maciej Musa Konopacki (ur. 1926) - nasz Tatar
}

DOI: http://dx.doi.org/10.12775/LC.2016.025

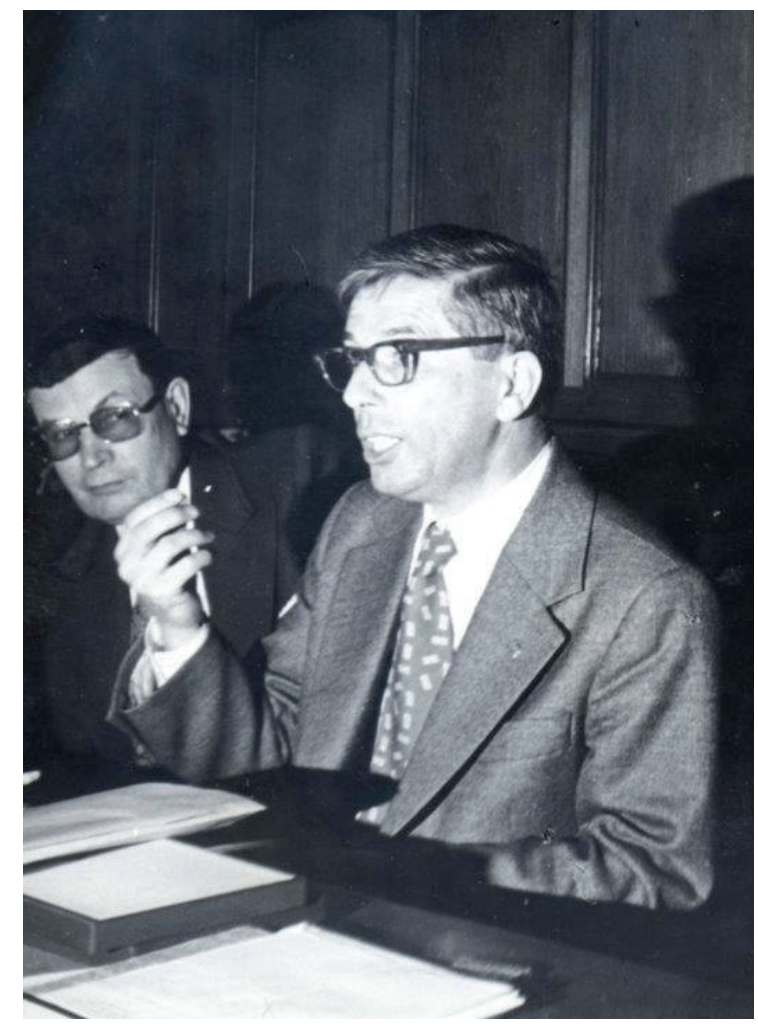

Maciej Konopacki podczas prelekcji pt. „Książka tatarska w Polsce” wygłoszonej 3 maja 1977 r. w Towarzystwie Przyjaciół Książki w Łodzi. Z lewej: inż. Edward Azarewicz.

(Z archiwum Macieja, Sopot, cop. 2009, 1 plyta CD)

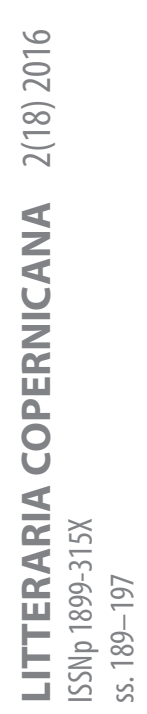


aciej Musa Konopacki to nietuzinkowy człowiek, którego historia rozpoczęła się 29 stycznia 1926 r. w Wilnie i wciąż się toczy. Chcąc opowiedzieć choć niewielką część tej historii, tak, by zabrzmiała wiarygodnie, oddaję w dużej mierze głos jej bohaterowi. Jego tekstom, wystąpieniom publicznym i prywatnym wypowiedziom.

Barwny styl tych wypowiedzi, ich dygresyjność i szczerość najtrafniej oddadzą osobowość muzułmanina, Tatara, wilnianina, sopocianina, dziennikarza, społecznika, Człowieka Dialogu, Macieja Musy Konopackiego, który przez całe życie zawodowe i pozazawodowe był zaangażowany w działalność popularyzującą szeroko rozumianą Tatarszczyznę, a także ideę porozumienia i dialogu chrześcijańsko-muzułmańskiego.

Pierwszy okres pracy zawodowej świeżo upieczonego wtedy rusycysty przypada na połowę lat 50. Początki dziennikarskiej kariery były związane z Redakcją Wiadomości Zagranicznych PAP, w której pracę podjął w roku 1955, tym samym, w którym ukończył studia na Uniwersytecie Warszawskim. Po dwóch latach pracy w PAP dołączył do białostockiej redakcji tygodnika białoruskiej mniejszości „Niwa”, w którym już wcześniej, bo 15 lipca 1956 r. (cztery miesiące po ukazaniu się pierwszego numeru tego pisma) opublikował swój pierwszy, oparty na pracy magisterskiej (nt. Janka Kupała jako ttumacz poezji Adama Mickiewicza, Wtadystawa Syrokomli i Marii Konopnickiej) artykuł Янка Kynaла - вялікі прылиель польскай літаратуры. W „Niwie” pracował do 1964 r. ${ }^{1}$

Równolegle rozpoczął współpracę z Polskim Radiem Białystok, które 15 czerwca 1958 r. nadało „Magazyn Białoruski”, pierwszą audycję w języku białoruskim zrealizowaną pod redakcją Konopackiego. Rozgłośnia, z którą młody redaktor związał się na kolejne dwa lata (1958-1960), do dziś poświęca mniejszościom narodowym najwięcej czasu antenowego na tle innych stacji radiowych ${ }^{2}$.

Pochodzenie, wyznanie, doświadczenia dzieciństwa były z pewnością czynnikiem determinującym podejmowane w pracy zawodowej tematy. Wkrótce motywem przewodnim artykułów Macieja Konopackiego stała się ta część jego tożsamości, z którą do dziś jest kojarzony przede wszystkim.

Jednym z pierwszych napisanych przez niego tekstów, zwracających uwagę na istnienie tatarskiej mniejszości, był wydany w „Turyście” artykuł Otoczmy opieka rodzimy Orient! . Kolejne pojawiały się m.in. na łamach „Gazety Białostockiej”, „Przeglądu Orientalistycznego”, „Literatury Ludowej”, krajoznawczo-turystycznego miesięcznika „Poznaj Swój Kraj”, a także białoruskojęzycznej „Niwy”. Były to tytuły prasowe docierające do szerokiego grona odbiorców, którzy mieli okazję zapoznać się i oswoić z podlaskim Orientem, a może nawet szerzej nim zainteresować. Można uznać, że Konopacki trafiał do różnych kręgów zawodowych i społecznych. Z jednej strony na szlak tatarski, do

1 R. Berger, Hassan Konopacki - Tatar, muzułmanin, bydgoszczanin, Warszawa 2011, s. 11; M. Pieciukiewicz, Listy (1956-1982), Białystok 2005, s. 19; Л. Глагоўская, Увесь свет Мацея Канапацкага, „Ніва”, nr 7 (2336), z dn. 18 lutego 2001 r., s. 5.

2 M. Pieciukiewicz, op. cit., s. 19; A. Ryczkowski, Słuchalność programów dla mniejszości narodowych emitowanych przez Polskie Radio Białystok na podstawie badań audytorium radiowego Instytutu Millward Brown SMG/K, ,Pogranicze. Studia Społeczne” 2011, t. XVIII, s. 203.

3 M. Konopacki, Otoczmy opieką rodzimy Orient!, „Turysta” 1960, nr 21 (146).

4 I. Radziszewska, Bibliografia prac Macieja Musy Konopackiego. Wybór, [w:] Tatarzy Wielkiego Księstwa Litewskiego w historii, języku i kulturze, red. J. Kulwicka-Kamińska, Cz. Łapicz, Toruń 2013, s. 33-41. 
Bohonik i Kruszynian, kierował czytelników zainteresowanych turystyką, którzy nie tylko z jego pierwszymi artykułami wyciętymi z gazet, ale już w latach 70. z broszurowymi przewodnikami Pod białostockimi minaretami ${ }^{5}$ lub Białostocki Szlak Tatarski ${ }^{6}$ mogli wyruszyć w podróż po ówczesnym województwie białostockim. Z drugiej strony współdziałał ze środowiskiem naukowym, które zaczęło coraz wnikliwej przyglądać się mniejszości tatarskiej, a szczególnie spuściźnie piśmienniczej Tatarów Wielkiego Księstwa Litewskiego. W swoim artykule Piśmiennictwo Tatarów polsko-litewskich w nauce polskiej i obcej, jako prekursora dyscypliny zwanej dziś kitabistyką, Konopacki wymienia Antoniego Muchlińskiego, który już w latach 50. XIX w. zainteresowal się słowiańskojęzycznymi fragmentami tekstów w tatarskich rękopisach religijnych ${ }^{7}$.

Przełom lat 50. i 60. był, jak mówi sam dziennikarz o czasie swojej aktywnej działalności, początkiem jego „okresu burzy i naporu”. Ale podczas gdy literacki Sturm und Drang trwał niecałe 20 lat, u Konopackiego, biorąc pod uwagę wydane teksty jego autorstwa, kończy się on po około 50 latach, jeżeli za ostatni opublikowany tekst uznać wstęp do wydawnictwa albumowego Tatarzy polscy. Historia i kultura Tatarów w Polsce $e^{8}$ które upamiętnia wystawę prezentowaną na Zamku Książąt Pomorskich w Szczecinie.

Publikacje w różnego rodzaju periodykach stanowią dużą i namacalną część jego działalności, co zostało odnotowane m.in. w informatorze Mniejszości narodowe $i$ etniczne w Polsce, w którym stwierdza się, że „największy dorobek publicystyczny ma dziennikarz Maciej Konopacki, wiele publikacji historycznych przygotowali również historyk Ali Miśkiewicz oraz Selim Chazbijewicz, znany również z publikacji poezji”".

Pierwsze kroki w popularyzowaniu kultury mniejszości tatarskiej stawiał, jak się okazuje, na długo przed debiutem na łamach prasy. Już w Szkole Powszechnej w Wilnie nauczycielka, pani Władysława Traczowa zamówiła u Macieja - wówczas ucznia piątej klasy - lekcję o islamie. Przyszły dziennikarz podszedł do zadania profesjonalnie, odbył konsultacje u muftiego Jakuba Szynkiewicza, a prelekcję przygotował na podstawie wypożyczonego mu przekładu Koranu z 1858 r. (tzw. Koranu Buczackiego) ${ }^{10}$.

5 M. Konopacki, Pod białostockimi minaretami, Białystok 1972.

6 Idem, Białostocki szlak tatarski, Warszawa 1977.

7 Idem, Piśmiennictwo Tatarów polsko-litewskich w nauce polskiej i obcej, „Przegląd Orientalistyczny” 1966, nr 3 (59), s. 193.

8 Idem, Bez tytułu - wstęp, [w:] Tatarzy polscy. Historia i kultura Tatarów w Polsce, red. B. Igielska, Szczecin 2009, s. 5-6.

9 Mniejszości narodowe i etniczne w Polsce. Informator 2003, red. L. M. Nijakowski, S. Łodziński, Warszawa 2003, s. 66.

10 Wspomnienia M. M. Konopackiego. Rozmowa z dn. 15 sierpnia 2015 r., Sopot. 


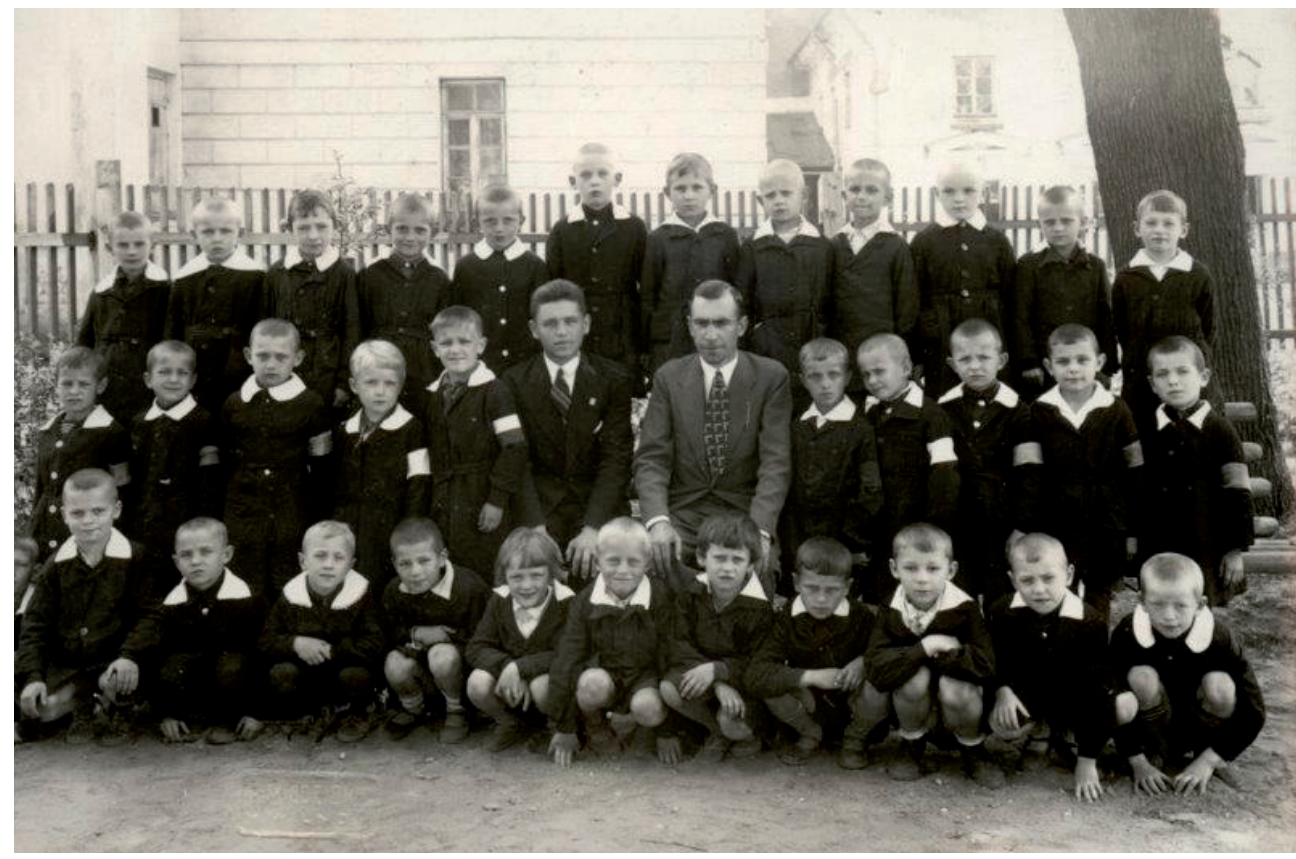

Szkoła Powszechna nr 1 im. Szymona Konarskiego, Wilno 1938 r., Maciej Konopacki w rzędzie kucających dzieci, czwarty z lewej. ( $Z$ archiwum Macieja, Sopot, cop. 2009, 1 płyta CD)

Aktywna działalność dziennikarza, po pobycie na Wybrzeżu w latach 1964-1972, ponownie przeniosła się na Białostocczyznę. W 1973 r. Konopackiego zatrudniono w Wojewódzkim Domu Kultury w Białymstoku, a w parę lat później w Powiatowym Domu Kultury w Sokółce, przekształconym w 1975 w Sokólski Ośrodek Kultury ${ }^{11}$. Tam rozpoczął starania o stworzenie działu tatarskiego w przyszłym Muzeum Społecznym. O realizowanym projekcie pisał w artykule Tatarszczyzna polska $w$ muzealnym ksztatcie:

Inicjatywa zrodziła się w Białymstoku. [... ] Nie wykroczono jednak poza sferę rozważań wokół celowości urządzenia w Muzeum Okręgowym w Białymstoku nawet skromnej ekspozycji. [...]

Do projektu utworzenia ekspozycji tatarskiej nawiązano dopiero w 1973 roku w memoriale przedłożonym Wydziałowi Kultury i Sztuki Urzędu Wojewódzkiego w Białymstoku. Memoriał przygotowali Zbigniew Żuk i autor tych słów. Wydział odniósł się z pełnym zrozumieniem do projektu.

[... Przychylono się do zdania, że położona w niedalekim sąsiedztwie Białegostoku oraz Bohonik i Kruszynian Sokółka, sama również stanowiąca spore skupisko Tatarów, jest najlepszym miejscem, w którym można z powodzeniem realizować projekt i to z korzyścią dla przyszłego Muzeum Ziemi Sokólskiej ${ }^{12}$.

W artykule został również opisany rysujący się kształt tworzonego działu tatarskiego oraz zebrane dotychczas eksponaty, które po raz pierwszy zaprezentowano w 1974 r. na wy-

11 J. Konopacki, "Sokólski Orient”, „Świat Islamu” 1996, nr 4, s. 8; D. Łotowska, Z kart historii Domu Kultury w Sokółce, ,Dyskusja: Biuletyn Wojewódzkiego Domu Kultury w Białymstoku" 1986, nr 8, s. 23.

12 M. Konopacki, Tatarszczyzna polska w muzealnym kształcie, „Przegląd Orientalistyczny” 1976, nr 2, s. 162. 
stawie w Bibliotece Miejskiej. Zaakcentowano także nieocenione wsparcie nieżyjącego już wówczas orientalisty Jana Reychmana. Autor zasugerował wreszcie, że finał realizacji projektu można połączyć z przypadającą na 1979 r. 300-setną rocznicą osadnictwa tatarskiego na Białostocczyźnie i Lubelszczyźnie ${ }^{13}$.

Jego poczynania nie zawsze spotykały się z aprobatą współwyznawców. Nie wszyscy umieli uruchomić wyobraźnię, spojrzeć w przyszłość i dostrzec właściwy cel działań Konopackiego $^{14}$. Zapewne dlatego o swoich tatarskich korzeniach po latach mówi:

Trawestując słowa Gombrowicza, jestem doprowadzony do ostateczności swoim pochodzeniem i swoją świadomością, jest mi z tym bardzo trudno i bardzo dobrze, lubię pokonywać aporie i jakoś to mi się udaje, inszallah ${ }^{15}\left({ }^{16}\right)$.

Przywracając temat tatarskiego osadnictwa społeczności lokalnej oraz zainteresowanym w całym kraju, Konopacki stał się również pomysłodawcą oraz jednym z organizatorów imprezy „Orient Sokólski”. Pierwszy „Orient Sokólski - prawda i legenda”, który stał się imprezą cykliczną, odbył się w dniach 26-27 czerwca 1976 r. Kolejny zorganizowano 30 czerwca i 1 lipca wspomnianego już 1979 r., szczególnego, ze względu na okrągłą rocznicę tatarskiego osadnictwa, a także na towarzyszące imprezie wydarzenia. W ramach obchodów rocznicy otwarto bowiem nowy szlak turystyczny, nazwany „szlakiem tatarskim”, który wiódł z Białegostoku do Sokółki, a następnie do Bohonik i Kruszynian, natomiast Muzeum Okręgowe przekazało „tatariana” tworzące odrębną ekspozycję w Muzeum Społecznym ${ }^{17}$.

$\mathrm{Na}$ fali popularności tematu, jak również niemałej popularności osobistej, Konopacki, jako osoba zasłużona dla regionu, powrócił do Polskiego Radia Białystok, tym razem w roli eksperta. W audycji Janiny Raczkowskiej Trzy opowieści z tatarskiego szlaku - część III, poświęconej rodowodom tatarskim w literaturze polskiej, wyemitowanej 12 stycznia $1978 \mathrm{r}$., został przedstawiony jako: „Tatar z pochodzenia, wybitny znawca polskiego Orientu, twórca działu tatarskiego Muzeum Ziemi Sokólskiej” ${ }^{18}$. Omawiając liczne wątki literackie, Konopacki porusza w audycji również kwestie poczucia tożsamości etnicznej, wyznaniowej, kulturowej oraz poszukiwania własnych korzeni:

Fascynują mnie losy Tatarów, aż do zatracenia się ich w polskości, aby, po nieraz kilku pokoleniach, mogła ożyć legenda o innoplemiennych przodkach. [...] Na pewno nie będę w błędzie, jeśli dodam, że to poszukiwanie jakiejś odrębności, poszukiwanie korzeni pochodzenia jest w naszych czasach już całym zjawiskiem. Po prostu w ten również sposób jakby bronimy się

13 Ibidem, s. 161-164.

14 Ibidem, s. 162; idem, „Ex oriente lux" po rodzimemu, [w:] Tatarzy polscy. Jednodniówka w 20. rocznicę I"Orientu Sokólskiego", red. K. Andrzejewska, Białystok-Sokółka 1996, s. 21; idem, Wspólnota utraconych szans?, „Życie Tatarskie” 1998, nr 1 (70), s. 13-16; L. Olchowik, Pobratymiec, llustrowany Magazyn Turystyczny „Światowid” 1987, nr 3 (931), s. 15.

15 Ar. in šā'a Allāh - zwrot wyrażający nadzieję na spełnienie czegoś, jeśli taka jest wola Boga, ,jeżeli zechce Bóg" (S. Stachowski, Glosariusz turecko-polski, Kraków 2005, s. 134).

16 Wypowiedź z 2003 r., zarejestrowana prawdopodobnie (nieopisany dokument dźwiękowy) podczas obchodów III Dni Kultury Muzułmańskiej, 9-12 października 2003 r., Gdańsk. Maciej Konopacki [dokument dźwiękowy w formacie MP3], [w:] Z archiwum Macieja, Sopot, cop. 2009, 1 płyta CD.

17 D. Łotowska, op. cit. s. 24; A. Miśkiewicz, Orient Sokólski (z działalności Sokólskiego Ośrodka Kultury) „,"Dyskusja: Biuletyn Wojewódzkiego Domu Kultury w Białymstoku" 1986, nr 8, s. 25-26.

18 J. Raczkowska, Trzy opowieści z tatarskiego szlaku - część III, Polskie Radio Białystok, 12 stycznia 1978 r. [dokument dźwiękowy w formacie MP3], [w:] Z archiwum Macieja, Sopot, cop. 2009, 1 płyta CD. 
przed utratą indywidualności w świecie, który pragnie nas zuniformizować, zewnętrznie i wewnętrznie upodobnić jednych do drugich, po prostu uczynić nas w tym cywilizacyjnym tyglu jakąś papką. [...] A broniąc się przed utratą tej indywidualności, nieraz penetrujemy swe rodowody, swą genealogię i nawet domniemana tatarskość potrafi jakoś krzepić, czy świadomość w ogóle jakiejś inności. [...] Uświadamianie autentyczności w przeszłości, im bardziej odległej, pozwala przetrwać niejedną ciężką próbę życia człowiekowi, godnie znosić przeciwności losu. Nasuwa się w tej chwili i takie jeszcze spostrzeżenie, które kiedyś zasłyszałem, a tu w wolnym przekazie powtórzę, oto tracąc świadomość swej genealogii, gubimy klucz do zrozumienia zarówno siebie samych, jak i otaczającego nas świata kultury ${ }^{19}$.

Autor tych słów sam stał się specjalistą od orzekania o tatarskości. Podczas Biesiady tatarskiej w gdańskiej Tawernie Mestwin (12 czerwca 2004 r.) przyznał: „Moje zbiory puchną od listów, również z obcych krajów. Chcą, żebym ja uwierzytelnił ich tatarskie pochodzenie. Przecież ani większy wymiar emerytury nie będzie, ani renty. Tatarszczyzna tak tkwi w krwioobiegu Słowian"20.

Większość tej bogatej i cennej korespondencji została uporządkowana i ocalona w publikacjach przygotowanych przez Rafała Bergera, naczelnego imama Stowarzyszenia Jedności Muzułmańskiej. Kolejne tomy: Dżennet do Macieja ${ }^{21}$, Ułani do Macieja ${ }^{22}$, Literaci do Macieja ${ }^{23}$ oraz Profesorowie do Macieja ${ }^{24}$ zawierają zarówno epizodyczne kontakty listowne, jak i długoletnią, regularną korespondencję. Publikacje te uświadamiają rozległość działań i mnogość znajomości Konopackiego, a także zaufania i sympatii, jaką autorzy listów darzyli ich adresata. Skąd ta sympatia? Popularny Tatar ma teorię:

Bo jak wiemy, jest tak zwany feblik tatarski, faible - „sympatia”. Coś to jest w tym narodzie polskim, że do nas lgną, nam się zwierzają, a nie powiedzą swoim współwyznawcom. Niektórzy hierarchowie kościelni mówią mi to, czego nie powiedzą współhierarchom. Ja natomiast mówię im to, czego nie powiem współmuzułmaninowi ${ }^{25}$.

Z całą pewnością „feblik tatarski” działał w stosunku do Konopackiego.

Całokształt aktywnych działań, które trwały, jak się okazuje, blisko pół wieku, można nazwać łączeniem środowisk: białoruskiego, wileńskiego i pomorskiego, tatarskiego i polskiego, muzułmańskiego i katolickiego. Łączył, bo nie uznaje granic między nimi:

Ponieważ należę do wspólnoty tatarskiego pochodzenia wyznania muzułmańskiego, a nasi współplemieńcy mieszkają też na Litwie i na Białorusi, a więc jednako są mi bliskie te trzy narody i zniosłem granice w świecie wewnętrznym między tymi krajami, a z konieczności musiałem

\footnotetext{
19 Ibidem.

20 Biesiada tatarska odbyła się w Gdańsku w ramach IV Dni Kultury Muzułmańskiej w Polsce (5-19 czerwca 2004 r.), 3_Maciej Konopacki, 12 czerwca 2004 r. [dokument dźwiękowy w formacie MP3], [w:] Z archiwum Macieja, Sopot, cop. 2009, 1 płyta CD.

21 Dżennet do Macieja, red. M. Berger, R. Berger, Warszawa 2012.

22 Ułani do Macieja, red. R. Berger, Warszawa 2013.

23 Literaci do Macieja, red. R. Berger, Warszawa 2014.

24 Profesorowie do Macieja, red. R. Berger, Warszawa 2015.

25 Maciej Konopacki [dokument dźwiękowy w formacie MP3], [w:] Z archiwum Macieja, Sopot, cop. 2009, 1 płyta CD.
} 
dokument na granicy ukazywać, kiedy wędrowałem do mego rodzinnego, nigdy nieodżałowanego Wilna ${ }^{26}$.

Rodzinne Wilno musiał opuścić w 1946 r. Decyzja o wyjeździe na Zachód była spowodowana zagrożeniem wywiezienia na Wschód. Wybór był prosty. Rodzina Konopackich trafiła najpierw do Bydgoszczy, a po śmierci Hassana Konopackiego (1879-1953), ojca Macieja, przeniosła się w 1956 r. do Sopotu ${ }^{27}$.

Z czasem przyszło utożsamienie się z nową ojczyzną. Na wspomnianej już wcześniej biesiadzie z przedstawicielami mniejszości tatarskiej w Gdańsku, mówiąc o ekspatriacji, której doświadczył, zaznaczył: „Myśmy się tu nie znaleźli pierwsi [...] i nasze tradycje sięgają średniowiecza, a nawet Grunwaldu, bo Długosz wspomina Tatarów i pod Grunwaldem. Nasz kronikarz, nasz polski, nie inny żaden"28.

Parafrazując te słowa, można z kolei powiedzieć, że Maciej Musa Konopacki to zdecydowanie nasz Tatar, nasz, nie inny żaden, a stwierdzenie to mogłoby wybrzmieć zarówno w Gdańsku, Sopocie, Bydgoszczy, Białymstoku, Sokółce, jak i w Wilnie czy Mińsku, rodzinnym mieście jego ojca.

Sam w rozmowie z dziennikarką Anną Sobecką, prowadzącą w Radiu Gdańsk magazyn mniejszości narodowych Kalejdoskop, emitowany na antenie w latach 1995-2010, powiedział: „Niosę w sobie jakieś pierwiastki Wielkiego Księstwa Litewskiego i Rzeczpospolitej bynajmniej nie tylko Obojga Narodów. Stąd właśnie wypływa moje szczęście, a moja świadomość pomaga mi być blisko z tymi wszystkimi nacjami. Na ile mnie stać, daję temu wyraz w mojej publicystyce"29.

Konopackiemu zdarza się również mówić: „nasz biskup”, „nasz papież”. W jego publikacjach, równolegle z promowaniem kultury tatarskiej, pojawia się istotna dla niego kwestia dialogu międzyreligijnego i ekumenii. Temat ten wydaje się dominować w późniejszych tekstach autora ${ }^{30}$. W jednym z publicznych wystąpień przyznał: „Nie ten zbiera, kto sieje, powiedział dobry papież Jan XXIII, którego wielbię, bo od niego zaczyna się moja bardzo czynna już po II Soborze Watykańskim jakaś, nie lubię słowa, działalność”31.

Papież Jan XXIII i II Sobór Watykański zainspirował początkującego redaktora, a dojrzałego już człowieka do pisania w duchu ekumenii, ale niewątpliwie w dzieciństwie należałoby szukać źródeł jego wrażliwości na wielokulturowość i różnorodność wyznań. Można pokusić się o stwierdzenie, że ekumenia była dla małego Macieja rzeczą naturalną. O latach dziecięcych mówił:

\footnotetext{
26 Wypowiedź z 19 czerwca 2004 r., zarejestrowana podczas obchodów IV Dni Kultury Muzułmańskiej w Polsce, Gdańsk. Musa Konopacki - Gdańsk 2004, 19 czerwca 2004 r. [dokument dźwiękowy w formacie MP3], [w:] Z archiwum Macieja, Sopot, cop. 2009, 1 płyta CD.

27 A. Sobecka, Kalejdoskop. Spotkania z mniejszościami narodowymi, Gdańsk 2014, s. 156-157, 167-168; G. Niemyjska, R. Krawczykiewicz, Wywiad z Maciejem Musq Konopackim z 4 marca 2010 r., Cyfrowe Archiwum Pomorskich Kresowiaków [on-line]. Portal capk.pl [data dostępu: 26 VIII 2015]. Dostęp z: http://www.capk.pl/ content/maciej-musa-konopacki.

28 3_Maciej Konopacki, 12 czerwca 2004 r. [dokument dźwiękowy w formacie MP3], [w:] Z archiwum Macieja, Sopot, cop. 2009, 1 płyta CD.

29 A. Sobecka, op. cit., s. 168.

30 I. Radziszewska, op. cit., s. 37-38.

31 Maciej Konopacki [dokument dźwiękowy w formacie MP3], [w:] Z archiwum Macieja, Sopot, cop. 2009, 1 płyta CD.
} 
Otóż w naszym domu w Wilnie na piętrze drugim, byli następujący sąsiedzi. Vis-à-vis rodzina Kaczelników - żydowska. Po przekątnej ksiądz Adam Dobrski, zmarł w Łodzi w czasach biskupa Klepacza. Za ścianą rodzina państwa Łopattów z Trok - Karaimi. Ja po mieczu i kądzieli, po kądzieli i mieczu, bo matka jest przede wszystkim, jestem o korzeniach tatarskich [...]. Wdychało się na tym piętrze zapachy czterech kuchni. No naprawdę ktoś to wyreżyserował! Los - czytaj Bóg. I również wzajemnie myśmy się częstowali. Cztery religie, cztery święta pomnożone przez ich tam w ciągu roku ileśs ${ }^{32}$.

Liczne wykłady, odczyty na sesjach naukowych i sympozjach, relacje z tych wydarzeń, publikacje $\mathrm{w}$ duchu ekumenizmu drukowane $\mathrm{w}$ pokonferencyjnych zbiorach, w prasie katolickiej (m.in. „Gwiazda Morza”) i muzułmańskiej (m.in. „Świat Islamu”), zaowocowały tytułem Honorowego Wykładowcy Papieskiego Wydziału Teologicznego we Wrocławiu, przyznanym Konopackiemu 15 marca 2000 r. na posiedzeniu Towarzystwa Teologicznego ${ }^{33}$. Natomiast Rada Wspólna Katolików i Muzułmanów na nadzwyczajnym Walnym Zgromadzeniu 15 listopada 2008 r. przyznała mu „za całokształt jego działań na rzecz porozumienia oraz dialogu między chrześcijaństwem i islamem”34 tytuł Człowieka Dialogu, który w wręczono mu uroczyście w 2009 r. w Warszawie podczas obchodów IX Dnia Islamu w Kościele katolickim ${ }^{35}$.

Parafrazując słowa Ewangelii według św. Mateusza, można by rzec, że jednak nie samą Tatarszczyzną i ekumenią żyje człowiek. Zawodowa ścieżka Konopackiego była dość różnorodna. W latach 1949-1950 pojawił się w jego życiu epizod nauczycielski, kiedy to jeszcze przed podjęciem studiów rusycystycznych na Uniwersytecie Jagiellońskim (ukończonych na Uniwersytecie Warszawskim), po półrocznym kursie pedagogicznym uczył języka rosyjskiego w Liceum Pedagogicznym w Bydgoszczy ${ }^{36}$. Gdy po pierwszym „okresie białostockim" powrócił na Wybrzeże, był rzecznikiem prasowym Dyrekcji Gdańskiej Stoczni im. Lenina (1966-1972) 37. Po kolejnym powrocie z Podlasia do Sopotu (1977), nie porzucając dotychczasowych tematów i środowisk, otwarty na wszystkich i wszystko, podjął z właściwym sobie zaangażowaniem kolejne nowe działania. Pracował w Bałtyckiej Agencji Artystycznej BART w Sopocie ${ }^{38}$, a następnie, można powiedzieć, że znowu przyjął na siebie rolę prekursora, gdyż przyczynił się do założenia w 1979 r. Uniwersytetu Trzeciego Wieku przy Wojewódzkim Ośrodku Gerontologicznym w Gdyni ${ }^{39}$. Była to filia gdańskiego UTW. W tym samym okresie dodatkowo absorbującym go tematem, jako pracownika Ośrodka, stała się gerontologia, „bo ja jestem gerontologiem z zamiłowania” ${ }^{40}$ - wyznał szczerze pod-

32 Ibidem.

33 R. Chalembek, T. Sikorski, Maciej Musa Konopacki Honorowym Wykładowca Papieskiego Wydziału Teologicznego we Wrocławiu, Świat Islamu” 2001, s. 18.

34 A. Skowron-Nalborczyk, Człowiek dialogu [on-line]. Portal radawspolna.pl [data dostępu: 26 VIII 2015$].$ Dostęp z: http://www.radawspolna.pl/index0da1.html?option=com_content\&task=view\&id=55\&ltemid=1.

35 A. M. Piwko, Sprawozdanie z centralnych uroczystości związanych z obchodami IX Dnia Islamu w Kościele katolickim w Polsce [on-line]. Portal radawspolna.pl [data dostępu: 26 VIII 2015]. Dostęp z: http://www.radawspolna.pl/index486c.html?option=com_content\&task=view\&id=62\&ltemid=43.

36 R. Berger, op. cit., 49.

37 Л. Глагоўская, Увесь свет Мацея Канапацкага,„,Ніва”, nr 8(2337), z dn. 25 lutego 2001 r., s. 4; M.Pieciukiewicz, op. cit., s. 19.

38 Pracowała tam również jego siostra, Tamara Sokołowska (A. Sobecka, op. cit., s. 157).

39 R. Berger, op. cit., s. 12-13.

403 Maciej Konopacki, 12 czerwca 2004 r. [dokument dźwiękowy w formacie MP3], [w:] Z archiwum Macieja, Sopot, cop. 2009, 1 płyta CD w formacie MP3. 
czas wieczoru wspomnień zgromadzonym w Tawernie Mestwin miłośnikom Tatarszczyzny i swoim współwyznawcom.

Maciej Musa Konopacki to również komentator rzeczywistości. Jego opinie, listy, artykuły dotyczyły bieżących, istotnych na skalę krajową i światową wydarzeń. Po zamachu na World Trade Center z 11 września 2001 r. i reperkusjach w postaci wybicia szyb w meczecie w Gdańsku swoje zdanie wyraził w artykule Nieustannie rozróżniać opu-

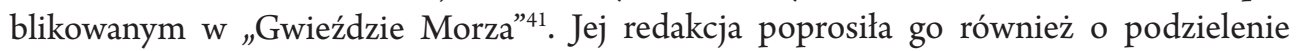
się refleksją na temat VIII pielgrzymki Jana Pawła II do Polski (16-19 sierpnia 2002 r.). Współkomentatorami tego wydarzenia na łamach pisma zostali Lech Kaczyński, wówczas poseł Prawa i Sprawiedliwości, oraz profesor Brunon Synak, ówczesny prezes Zrzeszenia Kaszubsko-Pomorskiego ${ }^{42}$. Po ataku terrorystycznym na szkołę w Biesłanie (1 września 2004 r.) wraz z Heleną Szabanowicz wysłał z kolei list do „Rzeczpospolitej”, jako głos w sprawie w imieniu Tatarów polskich ${ }^{43}$.

Wszelkie bieżące kwestie polityczne i społeczne, a także historia, która tworzy ich podłoże, były i nadal są ciekawym tematem do dyskusji, poszukiwania odpowiedzi, snucia refleksji i wspomnień, w których Maciej Musa Konopacki często powraca do Wilna i korzeni tatarskich. Energią naszego Tatara i jego apetytem na życie można by obdzielić kilka osób. Wspominając koleje swego losu, stwierdził: „życie jest ciekawe”44.

Iwona Radziszewska - doktor nauk humanistycznych w zakresie językoznawstwa, slawistka. Zajmuje się piśmiennictwem religijnym Tatarów Wielkiego Księstwa Litewskiego, pograniczem kulturowo-językowym, a także kulturą i religią islamu.

41 M. Konopacki, Nieustannie rozróżniać, „Gwiazda Morza” 2001, nr 20, s. 34.

42 Po papieskiej pielgrzymce, „Gwiazda Morza” nr 18, z dn. 1-8 września 2002 r., s. 16.

43 H. H. Szabanowicz, M. M. Konopacki, „Dziecięca apokalipsa” - głos Tatarów polskich, "Rzeczpospolita”, nr 215, z dn. 13 września 2004 r.

44 Rozmowa z 15 sierpnia 2015 r. 